\title{
INDONESIAN NAMES: A GUIDE TO BIBLIOGRAPHIC LISTING*
}

\section{A. Kohar Rony}

Since the establishment of the American Libraries Book Procurement Center in Djakarta by the Library of Congress in the fall of 1963, the flow of published materials from Indonesia has steadily increased, an encouraging sign for the development of Indonesian collections in this country. At the same time, it has brought sharply into focus numerous attendant problems. One of these problems is the uniform citation of Indonesian names on catalog cards and in bibliographies.

The problem in establishing a uniform citation of Indonesian names stems from their diversity and variety. This is understandable since Indonesia is not a homogeneous nation and the principle of "national" usage becomes difficult if not impossible to apply. Indonesia consists of 62 major ethnic groups which differ from one another in customs and languages. An Indonesian of one ethnic group may be knowledgeable about names in his own group but not necessarily about others, and usages in one group may not be appli cable to others. There is, therefore, very little uniformity in so far as "national" usage is concerned.

This is quite noticeable when it comes to listing names alphabetica11y. Name entries differ from one list to the next, depending upon the knowledge of the person who does the 1isting. In the absence of criteria set by an official Indonesian body, names having similar structures are entered either under the first element or last element, and sometimes such names are entered under both first and last elements.

In 1969 , I went to Indonesia to study its libraries, the library world, the book trade, and bibliographical activities and practices in genera1. As a result, I was able to meet with a number of librarians and bibliographers knowledgeable in the alphabetical listing of Indonesian names. On the basis of my studies, I would like to offer some provisional rules for the entry of Indonesian names in library catalogs and bibliographical citations.

\section{The Structure of Indonesian Names}

Before an alphabetical listing of names is possible, it is necessary to find some systematization in naming patterns. From the structural standpoint, it would appear that Indonesian names can be subsumed under four general categories:

* The views expressed here should not be construed as reflecting those of the Library of Congress, where the author is employed, nor of the Foreign Area Fellowship Program, to which he is grateful for funding the research of this study. 
1. Names which consists of a given name or names.

2. Names which consist of a given name or names and terms indicative of kinship, status, place of origin, or physical characteristics.

3. Names which consist of a given name or names and a family or clan name.

4. Names which consist of phrases or titles such as Tuanku Imam Bondjol meaning The Honorable Priest of Bondjol.

In this discussion, the following abbreviations will be used:

AN - Adult Name
BON - Birth Order Name
CN - Clan Name
FN - Family Name
GN - Given Name
HN - Honorific Name
HuCN - Husband's Clan Name
HuFN - Husband's Family Name
HuGN - Husband's Given Name
IN - Is lamic Name

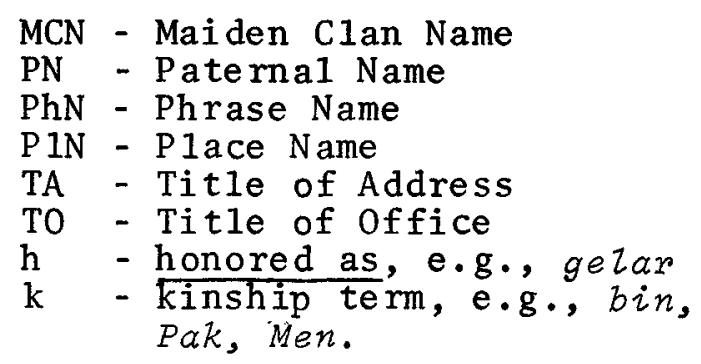

Names Which Consist of a Given Name or Names

An Indonesian given name may consist of one or more elements. It can be either a pure Islamic name or a mixed Islamic name or an indigenous name.

a. Is lamic names.

(1) One personal name: $\frac{\text { Muhammad }}{\mathrm{GN}}$

(2) Two common nouns: Amir Hakim

(3) A personal name and a common noun: Muhammad Amin

(4) Personal names of two Mus lim Prophets: Muhammad Adam

(5) A prefix Abdul with one of the ninety-nine beautiful names of God: $\frac{A b d u l ~ A z i z}{G N}$

(6) Kunyah: $\frac{\text { Abu Hanifah }}{\text { GN }}$

b. Mixed Is lamic names.

A combination of Islamic names with indigenous words or names: Achmad Subardjo GN

1. Kunyah is a proper noun indicating paternity and appears as a compound with $A b u$ as the first word. Originally the word $A b u$ indicated paternity, e.g., Abu Adenan (Father of Adenan), but now the word has lost its actual meaning. It is used as a personal name. Examples: Abu Bakar, Abu Daud, Abu Hanifah, Abu Kasim, Abu Tahir. 
c. Indigenous names,

(1) One personal name: $\frac{\text { Sudjatmoko }}{G N}$

(2) Two personal names: Harsini Setiasih

(3) Two common attributes: Bambang Sugeng

(4) A common noun and an attribute: Djoko Untung

Names Which Consist of Given Name(s) and Terms Indicative of Kinship, Status, Place of Origin, or Physical Characteristics

a. Given name followed by father's name or other as cendants .

(1) With inserted words anak, bin, binti, and ibni meaning "child of."

$\frac{\mathrm{Abdu} 11 \mathrm{ah}}{\mathrm{GN}} \frac{\mathrm{b} \text { in }}{\mathrm{k}} \frac{\mathrm{Nuh}}{\mathrm{PN}}$

$\frac{\text { Sitti }{ }^{2} \text { Fatimah }}{\mathrm{GN}} \frac{\text { binti }}{\mathrm{k}} \frac{\text { Muhammad Hassan }}{\mathrm{PN}}$

$\frac{\text { Banjang }}{\mathrm{GN}} \frac{\text { an ak }}{\mathrm{k}} \frac{\text { Janting }}{\mathrm{PN}}$

$\frac{\text { Nasiruddin Shah }}{\text { GN }} \frac{\text { ibni }}{\mathrm{K}} \frac{\text { Almarhum }}{\text { TA }} \frac{\text { Sultan }}{\text { TO }} \frac{\text { Zainal }}{\text { PN }}$

(2) Without the inserted kinship terms above.

(a) Written in Arabic style: Usman E1 Muhammady GN PN

(b) Non-Arabic style: $\frac{\text { Adam }}{\mathrm{GN}} \frac{\text { Malik }}{\mathrm{PN}}$

(3) Without the inserted kinship terms and with the father's name initialed.

$\frac{\text { Nungtjik }}{\mathrm{GN}} \frac{\mathrm{A} \text {. R. R. }}{\mathrm{PN}} \frac{\text { (Nungtjik }}{\mathrm{GN}} \frac{\mathrm{bin}}{\mathrm{k}} \frac{\mathrm{AbduI} \text { Roni) }}{\mathrm{PN}}$

$\frac{\text { Wishnu }}{\mathrm{GN}} \frac{\mathrm{D}}{\mathrm{PN}} \frac{(\text { Wishnu }}{\mathrm{GN}} \frac{\text { bin }}{\mathrm{K}} \frac{\text { Djajengminardo) }}{\mathrm{PN}}$

b. Given name followed by an adult name.

$\frac{\text { Sartono }}{\text { GN }} \frac{\text { Kartodirdjo }}{\text { AN }}$

2. Sitti or Siti is known among Indonesian Muslims as a title given to revered ladies of the Scripture, e.g., Sitti Hawa (Eve), Sitti Mariam (The Virgin Mary), as well as to ladies associated with the Prophet Muhammad, e.g., Sitti Fatima. In the Minangkabau region, the title is also used to address ladies of high position, but in other regions the title has been adopted as a name. 
c. Given name followed by adat title, which may or may not include the term gelar (honored as).

(1) Minangkabau: Rus tam Sutan Pa1indih GN HN

Abu Hanifah gelar Datuk Maharadja Emas GN $\mathrm{h} \frac{\text { HN }}{\mathrm{h}}$

(2) Palembang: Mochtar $\frac{\text { Prabu Mangkunegara }}{\text { GN }}$

d. Given name followed by place name or description of a physical characteristic, etc.

Abubakar Atjeh

$$
\text { GN } \frac{\text { PIN }}{\text { IN }}
$$

$\frac{\text { Mohammad Hassan }}{\text { GN }} \frac{\text { Ti ro }}{\text { PIN }}$

e. Given name preceded by Islamic name and title of address. Iskandar KaraEng Marang

f. Given name which may consist of one or more elements preceded by birth order name indicating order of seniority of children: Koman, Ketut, Njoman, etc.

Ketut Tantri

BON GN

$\frac{\text { Njoman }}{\text { BON }} \frac{\text { Suwandi Pendit }}{G N}$

g. Given name of the first born son or daughter preceded by such kinship terms as Men, Mák, Pan, Pak, etc.

$\frac{\text { Men }}{\mathrm{k}} \frac{\mathrm{Djaja}}{\mathrm{GN}}$

h. Given name followed by husband's given name. Lisma Rasjid (Husband's full name is Rasid Ibrahim)

Names Which Consist of Given Name(s) and Family or Clan Name

a. Given name(s) and Eamily name.

Emi 1 Salim

$\frac{\text { Edward }}{\text { GN }} \frac{\text { Paulus }}{G N} \frac{\text { Tirajoh }}{\text { FN }}$

b. Given name and husband's family name.

$\frac{\text { Paulina Siwabessy }}{\text { GN }}$

c. Family name and given name (Chinese tradition).

$\frac{\text { Ooi Cheng Kye }}{\text { FN }}$

d. Given name and clan name.

$\frac{\text { Apu1 }}{G N} \frac{\text { Lumbantobing }}{C N}$ 
e. Given name and husband's clan name and maiden clan name. Basariah Simorangkir-Simandjuntak GN $\mathrm{HuCN}$

f. Given name and clan name followed by honorific name. $\frac{\text { Apul }}{G N} \frac{\text { Lumbantobing ge lar }}{\mathrm{CN}} \frac{\text { Mangaradja Tanda }}{\mathrm{HN}}$

Names Which Consist of Phrases or Titles

a. Phrase names, consisting of phrases, generally are used as pseudonyms. They may or may not include part of author's real name.

Si Uma (Real name: Abdul Muis)

b. Title of office followed by place name.

Tuanku Imam Bondjo1 (Rea1 name: Muhammad Sahab)

\section{Proposed Rules for the Entry of} Indonesian Names ${ }^{3}$

Based upon the systematization of the naming patterns discussed previous $1 y$, I would like to recommend the following provisional rules for the entry of Indonesian names in library catalogs and bibliographical citations.

\section{Entry Element}

Enter ${ }^{4}$ the following categories of names, which do not contain family or clan names, under the first element of the name. Refer from the last element unless that element is an initial. In that case refer from the next to last element.

a. Names which consist of a given name or names.

Abdul Aziz

$$
\underline{x} \mathrm{Aziz}, \mathrm{Abdu}^{6}
$$

Muhammad Amin $\underline{x}$ Amin, Muh ammad

3. Since the preparation of this paper, the Library of Congress, in consultation with a group of Indonesian cataloging experts, including the author, has adopted a revision of Rule 57 ("Indonesian names") of the Anglo-American Cataloging Rules. This revision varies in major respects from the rules here and has been submitted to the American Library Association, the Canadian Library Association, and the (British) Library Association for final approval, which is pending.

4. The term "enter" means "make main entry"--the heading under which a complete record of a bibliographic entity is represented in the catalog, or, if there is no heading, a title.

5. The term "refer" means "see from one heading or entry to another."

6. The symbol " $x$ " is used to replace the word "refer" above. 
Bambang Sugeng

x Sugeng, Bambang

Harsini Sulastri

$x$ Sulastri, Harsini

b. Names which consist of given name(s) and terms indicative of

kinship, status, place of origin, or physical characteristics.

(1) Given name followed by father's name or other ascendants.

(a) With inserted words anak, bin, binti, etc.

$\mathrm{Abdu11ah}$ bin Nuh

$\underline{x} \mathrm{Nuh}, \mathrm{Abdullah} \mathrm{b}$ in

(b) Without the inserted words above.

Usman E1 Muhammady

$x$ Muhammady, Usman EI

Adam Ma1ik

$\underline{x}$ Malik, Adam

(c) Without the inserted words but with the father's name initialed.

Nungtjik A. R.

(2) Given name followed by an adult name.

Sartono Kartodirdjo

$\underline{x}$ Kartodirdjo, Sartono

(3) Given name followed by adat title, which may or may not include the term gelar (honored as). Sometimes the term gezar is abbreviated as $g z$ or $g z_{x}$. Omit gelar in the entry.

Rus tam Sutan Palindih

$$
\text { x Palindih, Rustam Sutan }
$$

Nasir Sutan Pamenan

Name appears as Nasir gelar Sutan Pamenan

X Pamenan, Nasir Sutan

Abu Hanifah Datuk Maharadja Emas

Name appears as Abu Hanifah gelar Datuk Maharadja Emas $x$ Hanifah, Abu, Datuk Maharadja Emas

$\underline{x}$ Emas, Abu Hanifah Datuk Maharadja

(4) Given name followed by place name or description of physical characteristics, etc.

Mohammad Hassan di Tiro

$$
\begin{aligned}
& x \text { di Tiro, Mohammad Hassan } \\
& \underline{x} \text { Hassan, Mohammad, of Tiro }
\end{aligned}
$$

(5) Given name preceded by Islamic name and title of address. Nadjamuddin Daeng Malewa

x Malewa, Nadjamudin Daeng

(6) Given name which may consist of one or more elements preceded by birth order name.

Ketut Tantri

x Tantri, Ketut 
(7) Given name of the first born son or daughter preceded by such words as Men, Mak and Pak etc.

Mak Selamin x Selamin, Mak

(8) Given name followed by husband's given name.

Lisma Rasjid $\underline{x}$ Ras jid, Lisma

c. Names which consist of phrases or titles.

(1) Phrase name

Si Uma x Uma, Si

(2) Title of office followed by place name. Tuanku Imam Bondjol $\underline{x}$ Bondjo1, Tuanku Imam

Enter an Indonesian whose name contains a family or clan name under his or her family or clan name. Refer from the name in direct order.

a. Given name(s) and family name.

Salim, Emi 1 $\underline{x}$ Emil Salim

b. Given name and husband's family name.

Siwabessy, Paulina $\underline{x}$ Paulina Siwabessy

c. Family name and given name (Chinese tradition).

Ooi, Cheng Kye Name appears as $00 i$ Cheng Kye $x$ Kye, Ooi Cheng $\underline{x}$ Ooi, Cheng-kye

d. Given name and clan name.

Lumb an tobing, Apul $x$ Apul Lumbantobing

e. Given name and husband's clan name and maiden clan name. Simorangkir-Simandjuntak, Bas ariah $x$ Simorangkir, Basariah Simandjuntak $\underline{x}$ Simandjuntak, Basariah Simorangkir

f. Given name and clan name followed by honorific name. (Omit the term gelar)

Lumb antobing, Apul, mangaradja tanda

\section{Titles}

Add titles and honorific words to Indonesian names according to the provisions of the rules $46 \mathrm{GI}$ and $49 \mathrm{~A} 3$ of the Anglo-American Cataloging Rules of $1967 .{ }^{7}$ Refer from the direct form of title plus name.

Purbatjaraka, raden mas ngabei $\underline{x}$ Raden, Mas Ngabei Purbatjaraka

7. See the appendix for a list of Indonesian titles. 
List of Indonesian and Malay Titles

Indonesian names are complicated by the use of titles, some of which may not be easily recognizable as titles and may be mistaken for one or more elements of the names themselves. These titles may also be abbreviated or the title and the first name may be abbreviated.

$$
\begin{aligned}
& \text { Examples: R. A. Kartini } \\
& \text { (Raden Adjeng: title only, all abbreviated) } \\
& \text { S. M. Abidin } \\
& \text { (Sutan Mochtar: title and name, a11 abbreviated) }
\end{aligned}
$$

The following list is by no means comprehensive:

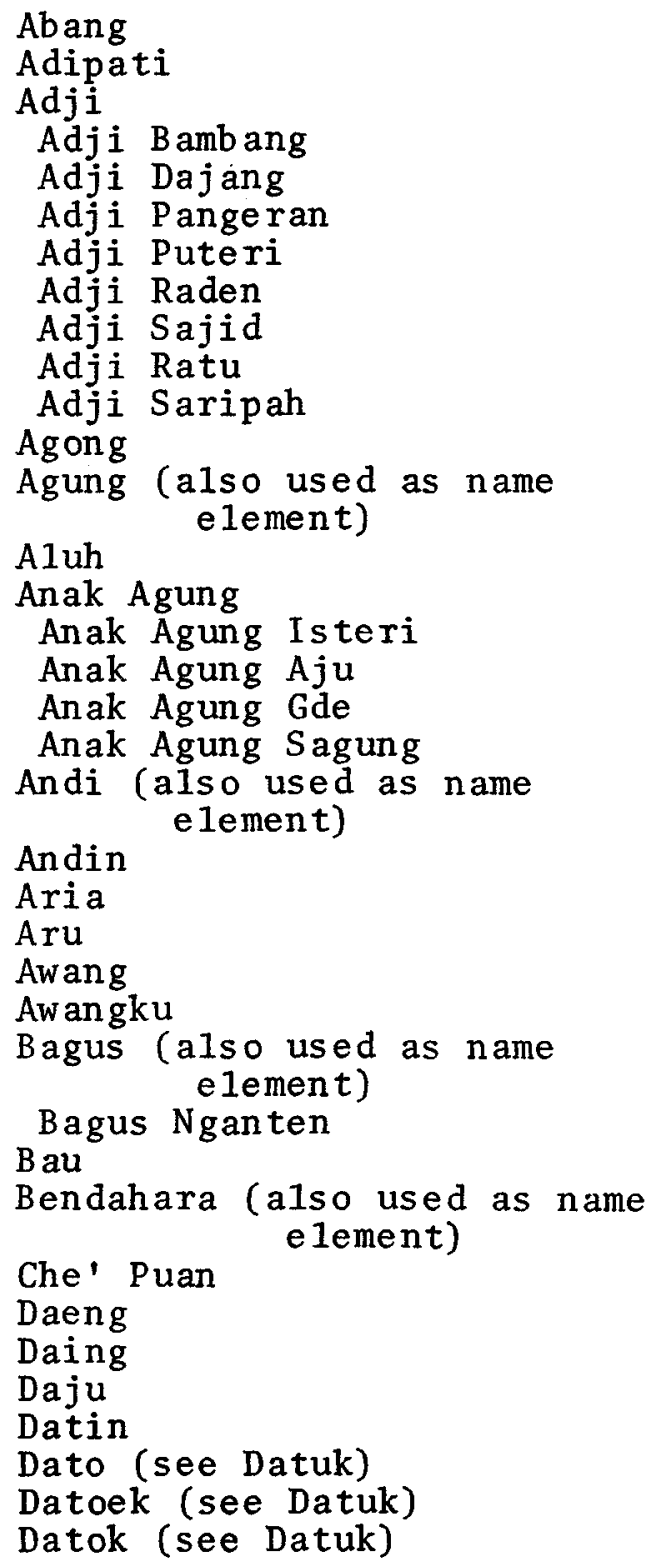

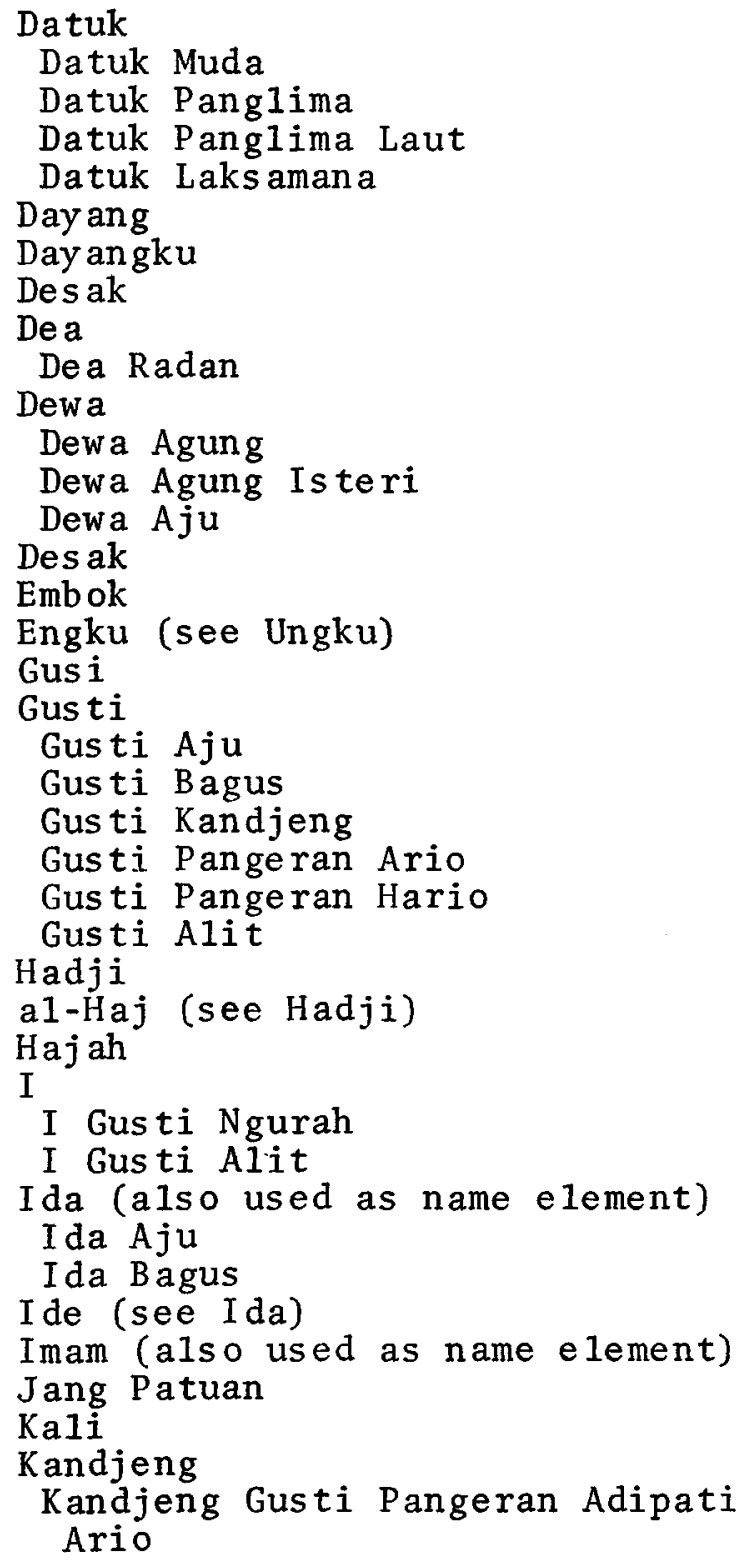




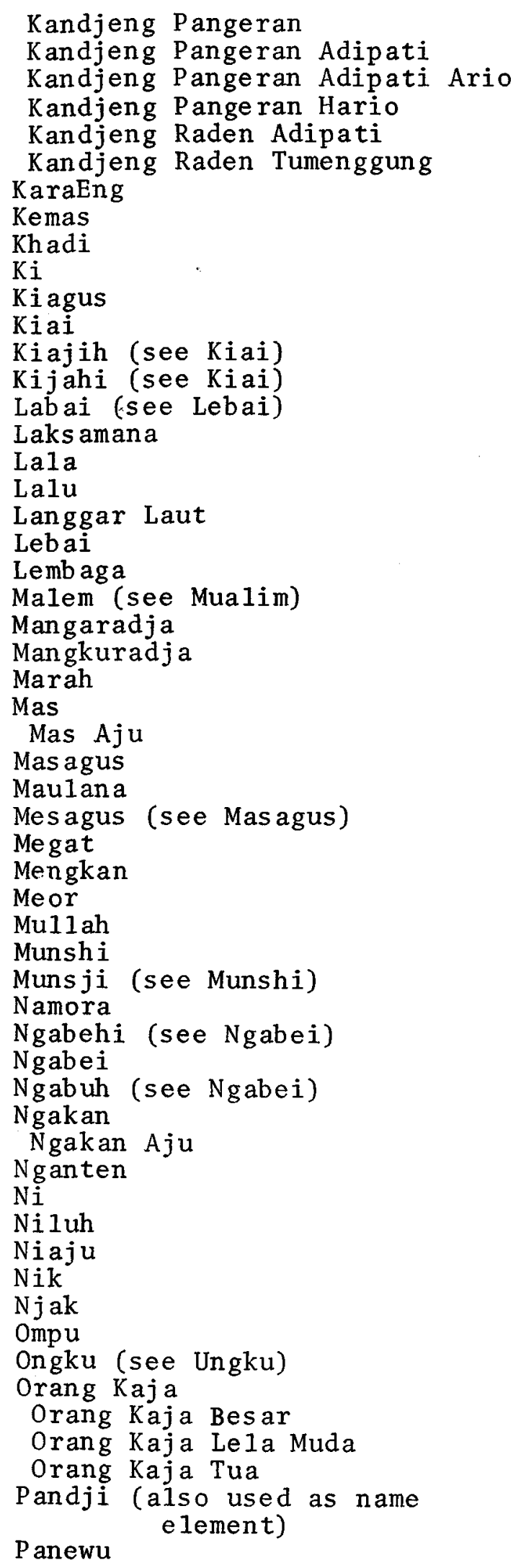

Pange ran

Pangeran Adipateh

Pangeran Adipati

Pangeran Adipati Anom

Pangeran Adipati Aria

Pangeran Ardjeuh

Pangeran Aria

Pangeran Ario

Pangeran Hario

Pange ran Ngabei

Pangeran $P$ and $j i$

Pangeran Putra

Pangeran Radja

Pangeran Radja Adipati

Pangeran Radjas a

Pangeran Rangga

Pangeran Ratu

Pangeran Sengkan

Pangeran Sentana

$P$ angeran Tumenggung

Pangeran Widjil

Panglima Laut

Panji (see Pandji)

Patta

Pedanda

Pengeran (see Pangeran)

Pengiran (see Pangeran)

Poteu Meureuhom

Poteu Radja

Potjut

Puan Sri

Puang Andi

Puang Patta

Putu

Rabu

Raden

Raden Adipati

Raden Adjeng

Raden Aju

Raden Aju Adipati

Raden Aju Tumenggung

Raden Ardjeuh

Raden Arja

Raden Bagus

Raden Djaka

Raden Lara

Raden Manggung

Raden Mas

Raden Mas Adipati

Raden Mas Aria.

Raden Mas Gusti

Raden Mas Ngabei

Raden Mas Pandji

Raden Mas Tumenggung

Raden Mas Tumenggung $P$ andji

Raden Mas ak

Raden Ngabei 
Raden Nganten

Raden Pandji

Raden Tumenggung

Radin

Radja (see Raja)

Raja

Raja Muda

Raja na opat

Raja Perbaringan

Rambu

Rangga

Ratoh (see Ratu)

Ratu

Ratu Arja

Ratu Bagus

Ratu Raja

Sajid (see Syed)

Saju

S ang

Sang Aju

Salit

Sayyid (see Syed)

Seri (see Sri)

Shahbandar

Shaikh (see sheikh)

Sharif (also used as name

Sharifah e lement)

Sheikh

Sheripah (see Sharifah)

Si

Sidi

Siti (also used as name element)

Sitti (see Siti)

$\mathrm{Sjahbandar} \mathrm{(see} \mathrm{Shahbandar)}$

Sjech (see Sheikh)

Sri (also used as name element)

Sri Narendra

Sri Paduka Kandjeng

Sultan

Sus uhunan

Sutan

Sutan Mangkutur

Sutan Naparas

Sutan Paruhun
Syed

Tan

Tan Sri

Temenggong (see Temenggung)

Temenggung

Tengku

Tengku Ampuan

Tengku Besar

Tengku Mahkota

Te ungku

Tjokorde

Tjokorde Gde

Tjokorde Isteri

Tjokordo (see Tjokorde)

T jut

Tjut Njak

Toh

Toh Puan

Toh Muda

Tuan

Tuanku

Tubagus (see Ratu Bagus)

Tus

Tubagus Raden

Tumenggung (see Temenggung)

Tun

Tun Datu

Tungku (see Tengku)

Tunku (see Tengku)

Ubu

U1 ama

Umb u

Undang

Ungku

Ungku Puan

Ustaz

Ustazah

Wan

Yang Di-Pertuan 